\title{
Rotifer communities of religious water bodies of Haryana (India): Biodiversity, distribution and ecology
}

\author{
Anita Bhatnagar* and Pooja Devi \\ Department of Zoology Kurukshetra University, Kurukshetra -136119 (Haryana), INDIA \\ *Corresponding author. E-mail: anitabhatnagar@gmail.com \\ Received: May 14, 2014; Revised received: August 20, 2014; Accepted: December 01, 2014
}

\begin{abstract}
The rotifer communities of eight religious water bodies of Haryana characterized by different trophic status reveal 44 species belonging to 15 genera and 12 families, represent the richest biodiversity of rotifers. Brachionus, Asplanchna and Keratella genus were found to be pollution tolerant species and common at all the selected water bodies viz., Brahmsarovar and Jyotisar at Kurukshetra; Saraswati tirth, Pehowa; Kapalmochan, Yamunanagar; Phalgu tirth, Kaithal; Banganga tirth , Dayalpur; Pandu Pindara, Jind and Kultarn Tirth, Kirmach. whereas Gastropus, Testudinella, Monostyla clasterocerca, Lecane arcula, Filina terminalis were found to be specific at Brahmsarovar (site 1); Filinia longiseta at Phalgu (site 2); Lecane ploenensis, Euchlanis dilata at Pehowa (site 3); B. budapestinensis, B. nilsoni, Asplanchna brightwelli, Asplanchna sieboldii, Polyurthera were specific to Kirmach (site 4); Monostyla decipiens, Anauraepsis nevicula at Jyotisar (site 5); Trichocera porcellus at Kapal mochan (site 7); Keratella cochlearis, Trichocera capucina were found to be specific at the BanGanga (site 8,). However, no specific species appeared at Pandu Pindara (site 6). Seasonal variations were also observed at all the sites during spring, monsoon, post monsoon and in winters. A positive correlation of rotifer abundance was observed with temperature $(r=0.356, P<0.05)$, BOD $(r=0.413, P<0.05)$ and Ammonia $(r=0.378, P<0.05)$ whereas a negative correlation was observed with DO $(r=-0.385, P<0.05)$ showing that these were the main factors affecting the richness, diversity and density of rotifers. The rotifer communities of each site can be reconstructed from the tables and figures making this inventory an important benchmark for evaluating future regional environment change.
\end{abstract}

Keywords: Plankton, Religious activities, Rotifer community, Species Diversity Indices, Zooplankton

\section{INTRODUCTION}

Rotifers are important ecological group in planktons occupying a wide range of habitat in aquatic ecosystem (Dhembare, 2012) and are thought to be the indicator of the trophic status of any aquatic body. These are also thought to be the pioneer organisms, appeared first in new created water body (Paleolog et al., 1997; Sulehria et al., 2009a). Studies on diversity of rotifers have been conducted by various workers (Duggan et al., 1998; Dhembare, 2011) but still little is known to date about the microfauna and zooplankton diversity in India due to general lack of taxonomic expertise.

India is a religious country where a range of practices are performed by cultural and religious communities that involve the use of water. Many rituals are associated with religious activities like immersion of idols, oil, floral offerings, wheat flour, ashes and mass bathing that further cause the addition of detergents, soap and other domestic wastes in water deteriorating the water quality (Bhatnagar and Sangwan, 2009). Haryana is a state where religious activities have its specific place in its cultural roots. Mass bathing and other rituals are associated here with many events like solar eclipse, new moon day, shrad period, pind dan, seasonal fairs etc. Although various studies have been done on the limnology of fresh water bodies in India (Kumar and Tripathi, 2004; Angadi et al., 2005; Tiwari and Chauhan, 2006) but effect of religious activities on the water quality of lentic water has been studied by only a few scientists (Sinha et al. 1991; Chandra and Prasad, 2005; Kulshreshtha and Sharma, 2006; Bhatnagar and Sangwan, 2009; Bhatnagar and Devi, 2012) and also no work has been done on the study of religious water bodies with respect to rotifers in Haryana, therefore the present study has been conducted to study the species composition, distribution and ecology of the rotifer communities of eight lentic water bodies of Haryana, India.

\section{MATERIALS AND METHODS}

Study area: A total of eight sites of water bodies have been selected in four districts (Fig.1) of Haryana (India) -Kaithal, Kurukshetra, Yamunanagar and Jind where maximum mass bathing and rituals activities are performed. Selected water bodies, their location and the religious activity at that site are shown in Table 1.

Sample collection: Two / three stations were selected at each of the eight sites on the basis of average number of pilgrims performing activity/mass bathing. 
Water samples were collected before and after religious activity in triplicate, in polythene bottles and also seasonally during Summer, Monsoon, Post monsoon and Winter from selected stations.

Physico-chemical analysis: The physico-chemical characteristics viz. temperature (atmospheric and water), $\mathrm{pH}, \mathrm{DO}$, free $\mathrm{CO}_{2} \mathrm{BOD}, \mathrm{COD}$, Ammonia, phosphate etc. were analyzed according to Standard procedures (Golterman et al., 1978; APHA, 2005).

Biological analysis: Plankton samples were collected by filtering $50 \mathrm{~L}$ of water through plankton net of mesh size $50 \mu \mathrm{m}$ with demarcating collecting tubes of 100 $\mathrm{ml}$ and the concentrated samples were made up to a standard volume of $40 \mathrm{ml}$ with distilled water and preserved in $4 \%$ formalin solution immediately after the sample collection. Planktons were quantified per liter using Sedgwick rafter cell method.

Number of planktons per liter $=\underline{\mathrm{P} \times \mathrm{C} \times 100}$ $\mathrm{L}$

Where, $\mathrm{P}=$ No. of planktons counted in ten fields: $\mathrm{C}=$ Volume of final concentrate of sample $(\mathrm{ml})$ and $\mathrm{L}=$ the volume of water sample filtered $(\mathrm{L})$

The number of plankton and their identification were done using the keys from Ward and Whipple (1959), Needham and Needham (1962), Battish (1992) and APHA (1998).

Diversity indices analysis: Shannon-Weaver Diversity Index, Index of Evenness (Simpson Index), Simpson Dominance Index (SDI), Percentage similarities (Sorensen Index) were calculated for the estimation of species diversity, distribution and composition of rotifers.

Species Diversity Index (d) Shannon Weaver Diversity Index: Species diversity of rotifers was determined using Shannon and Weaver Diversity Index method (Shannon and Weaver, 1963; Washington, 1984).

$\mathrm{d}=-\sum(\mathrm{ni} / \mathrm{N}) \log _{2} \mathrm{ni} / \mathrm{N}$

$\mathrm{d}=$ Species diversity

$\mathrm{ni}=$ Number of individuals of $\mathrm{i}^{\text {th }}$ species.

$\mathrm{N}=$ Total number of individuals in the sample

Index of Evenness (IE) Simpson's E.: Evenness can be defined as the measure of the relative abundance of different species making up the richness of an area, an important component of diversity indices (Hill, 1973; Turchi et al. 1995; Leinster \& Cobbold, 2012) and expresses evenly distribution of the individuals among different species.

For the calculation of evenness index:

Total number of rotifer $(\mathrm{N})$ was determined and thereafter Proportional representation of each rotifer was calculated. $\left(\mathrm{p}_{\mathrm{i}}\right)$. $=\mathrm{n} / \mathrm{N}$

These proportions $\left(\mathrm{p}_{\mathrm{i}}\right.$ 's) were squared and sum of these squares was calculated, i.e. $\sum \mathrm{p}_{\mathrm{i}}{ }^{2}$

Reciprocal value was determined, i.e. $1 / \sum \mathrm{p}_{\mathrm{i}}{ }^{2}$.

This quantity $\left(1 / \sum \mathrm{p}_{\mathrm{i}}^{2}\right)$ is known as Simpson's D, and is a measure of diversity.

To get evenness (E), D was divided by the total number of rotifer species present (which is the maximum possible value for $\mathrm{D})$. $E=\mathrm{D} / \mathrm{D}_{\max }$.

This index ranges from $1 / \mathrm{D}_{\max }$ to 1 (equal distribution of all habitats).

Simpson's index of dominance (SDI) was calculated according to Simpson's equation (Simpson, 1949):

$\mathrm{D}=\Sigma \mathrm{n}(\mathrm{n}-1) / \mathrm{N}(\mathrm{N}-1)$,

Sørensen-Similarity Index: The Sørensen similarity Index is a statistic method used for comparing the similarity between two samples.

$$
Q S=\frac{2 \mathrm{C}}{\mathrm{A}+\mathrm{B}}=\frac{2[\mathrm{~A} \cap \mathrm{E}]}{[\mathrm{A}]+[\mathrm{B}]}
$$

Where, $A$ and $B$ are the number of species in samples $\mathrm{A}$ and $\mathrm{B}$, respectively, and $C$ is the number of species shared by the two samples; QS is the quotient of similarity and ranges from 0 to 1 .

Statistical analysis: Group means, correlation among dependant and independent parameters was calculated using SPSS 11.5 version. Significant differences among treatment groups (Sites) were tested by Analysis of variance (ANOVA) Duncan's multiple range test for the water quality characteristics.

\section{RESULTS AND DISCUSSION}

Rotifers have versatile capacity to survive in different environments (Singh, 2000). A total of 44 species of rotifers were recorded from the eight water bodies of Haryana, India state during the entire period. Such study on biodiversity of rotifers has been carried out for the first time in water bodies of Haryana where religious activities are a regular feature. Anauraepsis fissa, B. angularis, B. calyciflorus, B. falcatus were the most common and dominant genera at most of the sites. Anauraepsis nevicula, Gastropus, Testudinella, Euchlanis dilata, B. diversicornis, B. bravispina, $B$. budapestinensis, $B$. nilsoni, $B$. bidendata, $B$. quadridentatus, B. caudatus, B. dimidiatus were the rare species found at different sites (Figs. 3, 4). Testudinella, Monostyla clasterocerca, Lecane arcula, Filina termanalis were found to be specific at the site 1, Brahmsarovar; B. budapestinensis, B. nilsoni, Asplanchna brightwelli, Asplanchna sieboldii, Polyurthera were specific to the site 4, Kirmach; Keratella cochlearis, Trichocera capucina at site 8, BanGanga, Trichocera porcellus at site 7, Kaplamochan, Lecane ploenensis, Euchlanis dilata at site 3, Pehowa, Filinia longiseta at site 2, Phalgu, Monostyla decipiens at site 5, Jyotisar were the site specific species found at respective sites.

A comparative analysis of rotifer diversity of different sites (Fig. 4) showed following trend: Brahmsarover (20 taxa) > Kirmach (18 taxa) Phalgu (17 taxa) > Ban ganga (17 taxa) Pehowa (15 taxa) $>$ Pindara(15 taxa) $>$ Kapalmochan (10 taxa) > Jyotisar (9 taxa). The high diversity may be present due to habitats providing anchorage to the resting eggs (Arora and Mehra, 2003) and it may be due to availability of larger variety of 


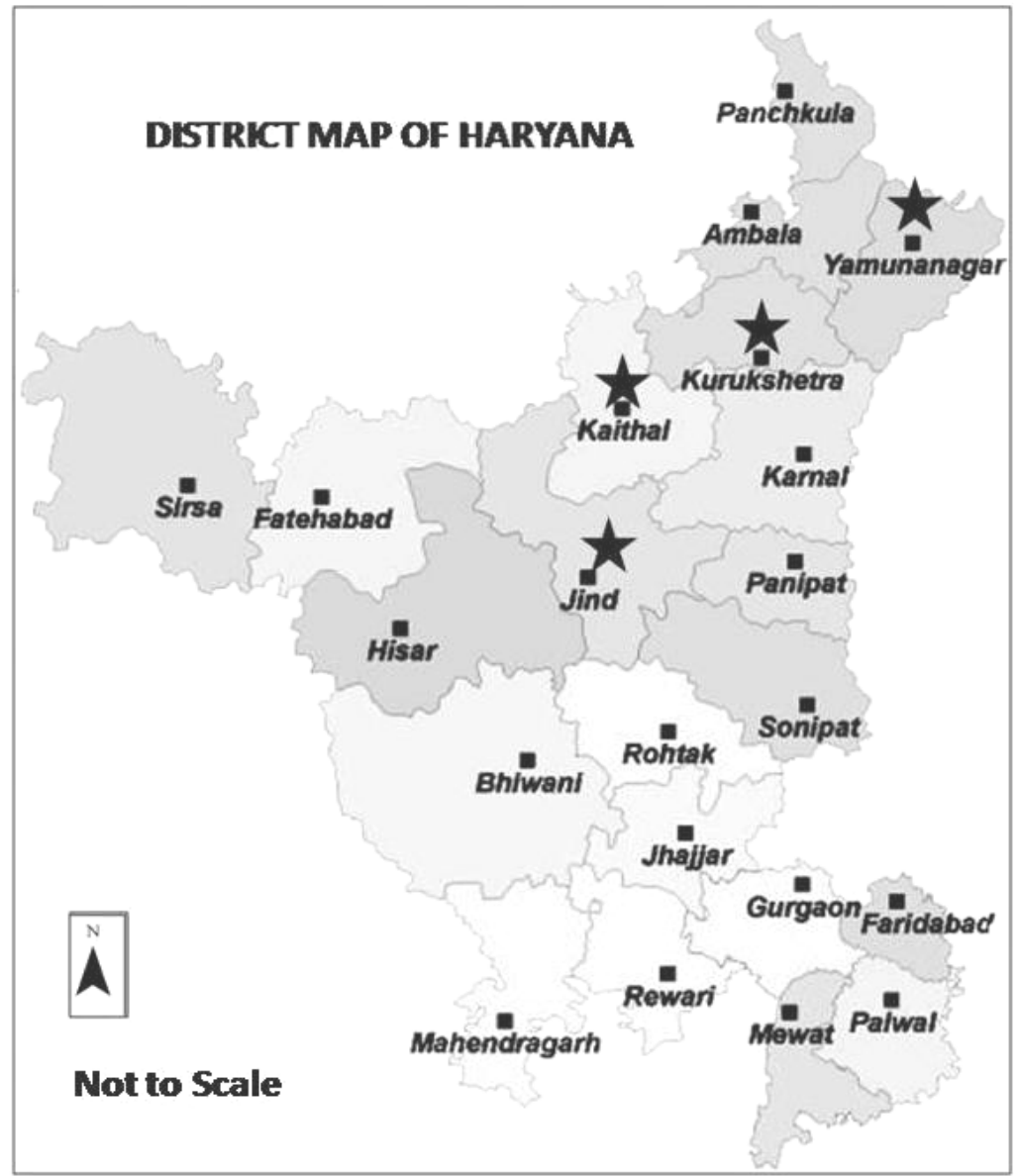

Fig. 1. Map showing selected districts of Haryana where religious activities are conducted in water bodies.

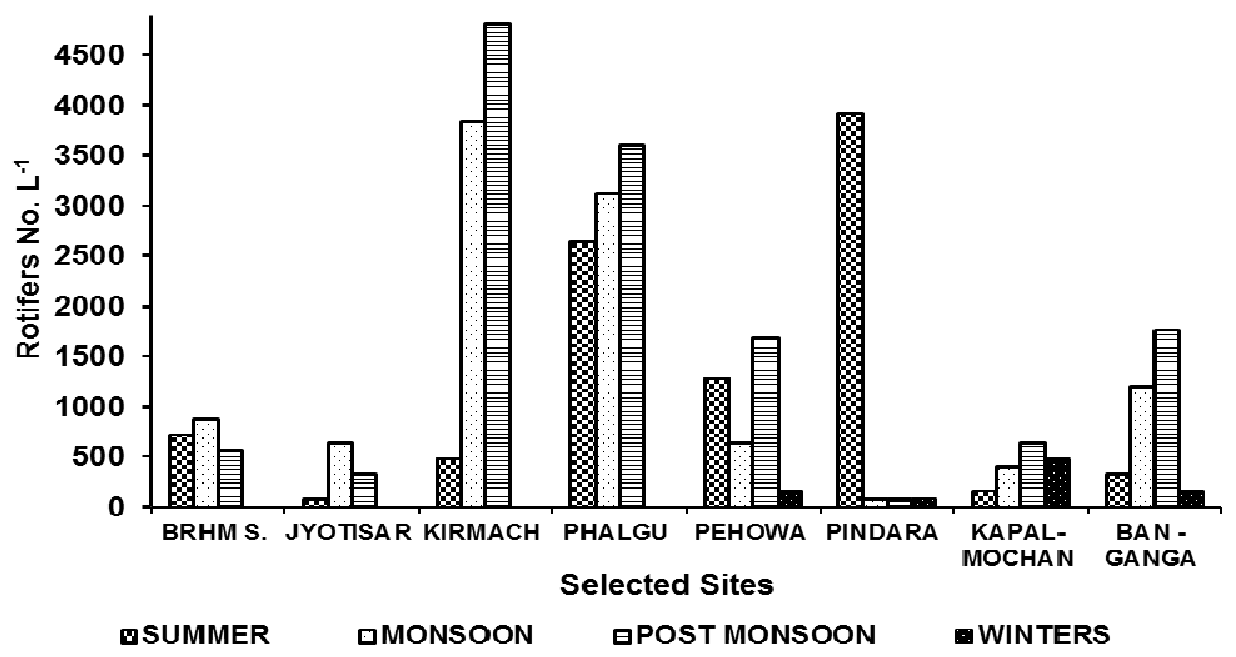

Fig. 2. Seasonal variation of Rotifer's population density in eight selected water bodies of Haryana.

microhabitats for colonization as these water bodies are not cemented at the floor. These results are similar to the observation of Edmondson, 1944; Wallace, 1977, 1980; Duggan et al., 1998. The least diversity of rotifers was recorded at the site Jyotisar (9 species). Family wise representation of recorded species showed the qualitative sequence as Brachionidae > Asplanachnidae $>$ Trichorceridae $>$ Lecanidae $>$ Filinidae.
No site wise definite trend of increase or decrease of total rotifer population was observed (Fig. 2). Seasonal abundance of rotifer population showed highest no./ L during Post Monsoon followed by Monsoon, Summer and Winters shown in the Fig. 2. The maximum abundance of rotifers were found at site Kirmach, Phalgu, Pehowa, Kaplamochan, Ban Ganga during post monsoon season than at Brahmsarovar and 
Table1. The selected water bodies, their location and the religious activities performed.

\begin{tabular}{|c|c|c|c|c|}
\hline $\begin{array}{l}\text { S. } \\
\text { No }\end{array}$ & $\begin{array}{l}\text { Name of water } \\
\text { body }\end{array}$ & District & $\begin{array}{l}\text { Latitude, } \\
\text { Longitude }\end{array}$ & Activity \\
\hline 1 & Brahmsarovar & Kurukshetra & $\begin{array}{l}29.961 \mathrm{~N} \\
76.827 \mathrm{E}\end{array}$ & $\begin{array}{l}\text { Mass Bathing on every New } \text { Moon } \\
\text { (Amavasya) and Solar eclipse day }\end{array}$ \\
\hline 2 & Saraswati tirth & $\begin{array}{l}\text { Pehowa, } \\
\text { Kurukshetra }\end{array}$ & $\begin{array}{l}29.978 \mathrm{~N} \\
76.596 \mathrm{E}\end{array}$ & $\begin{array}{l}\text { Pind-dan and bathing during Sharad, Solar eclipse } \\
\text { and Kartik New Moon day }\end{array}$ \\
\hline 3 & Kapalmochan & Yamunanagar & $\begin{array}{l}30.326 \mathrm{~N} \\
77.317 \mathrm{E}\end{array}$ & $\begin{array}{l}\text { Mass Bathing and Floral+ oil lamp offering on } \\
\text { Full Moon Day of Kartik (Oct./Nov) }\end{array}$ \\
\hline 4 & Phalgu tirth & $\begin{array}{l}\text { Pharal Village, } \\
\text { Kaithal }\end{array}$ & $\begin{array}{l}29.835 \mathrm{~N} \\
76.587 \mathrm{E}\end{array}$ & $\begin{array}{l}\text { Pilgrim Dip and rituals, like floral offerings on } \\
\text { New moon day (Amavasya) of Sharadh (Sept-Oct) }\end{array}$ \\
\hline 5 & Ban Ganga tirth & $\begin{array}{l}\text { Dayalpur, } \\
\text { Kurukshetra }\end{array}$ & $\begin{array}{l}29.937 \mathrm{~N} \\
76.813 \mathrm{E}\end{array}$ & Vaishakhi (seasonal fair) April \\
\hline 6 & Pandu-Pindara tirth & Jind & $\begin{array}{l}29.309 \mathrm{~N} \\
76.322 \mathrm{E}\end{array}$ & Somvati amvasya, Solar eclipse, Sharad \\
\hline 7 & Jyotisar & Kurukshetra & $\begin{array}{l}29.956 \mathrm{~N} \\
76.778 \mathrm{E}\end{array}$ & Solar eclipse \\
\hline 8 & Kultarn titrth, & $\begin{array}{l}\text { Kirmach, } \\
\text { Kurukshetra }\end{array}$ & $\begin{array}{l}29.922 \mathrm{~N} \\
76.806 \mathrm{E}\end{array}$ & Fair at Sept month \\
\hline
\end{tabular}

Table 2. Physico-chemical characteristics of water at all the selected sites (values are mean \pm S.E. of mean of 63 replicates).

\begin{tabular}{|c|c|c|c|c|c|c|c|c|}
\hline Parameter & Brahm S. & Phalgu & Pehowa & Kirmach & Jyotisar & Pindara & KapalM & Banganga \\
\hline Water Temp. & $\begin{array}{c}23.83^{\mathrm{ab}} \\
\pm 0.9\end{array}$ & $\begin{array}{c}25.583^{\mathrm{ab}} \\
\pm 1.37\end{array}$ & $\begin{array}{c}25.813^{\mathrm{ab}} \\
\pm 0.98\end{array}$ & $\begin{array}{c}30.323^{\mathrm{ab}} \\
\pm 0.38\end{array}$ & $\begin{array}{c}23.883^{\mathrm{ab}} \\
\pm 1.03\end{array}$ & $\begin{array}{c}22.793^{\mathrm{ab}} \\
\pm 0.82\end{array}$ & $\begin{array}{c}22.753^{\mathrm{ab}} \\
\pm 1.59\end{array}$ & $\begin{array}{c}23.3^{\mathrm{ab}} \\
9 \pm 1.03\end{array}$ \\
\hline $\mathrm{pH}$ & $\begin{array}{l}7.13^{\mathrm{ab}} \\
\pm 0.05\end{array}$ & $\begin{array}{l}7.003^{\mathrm{ab}} \\
\pm 0.06\end{array}$ & $\begin{array}{c}7.013^{\mathrm{ab}} \\
\pm 0.07\end{array}$ & $\begin{array}{c}7.213^{\mathrm{ab}} \\
\pm 0.05\end{array}$ & $\begin{array}{c}7.483^{\mathrm{ab}} \\
\pm 0.11\end{array}$ & $\begin{array}{c}7.023^{\mathrm{ab}} \\
\pm 0.14\end{array}$ & $\begin{array}{c}7.143^{\mathrm{ab}} \\
\pm 0.04\end{array}$ & $\begin{array}{c}7.163^{\mathrm{ab}} \\
\pm 0.04\end{array}$ \\
\hline $\begin{array}{l}\text { Free } \mathrm{CO}_{2} \\
\left(\mathrm{mg} \mathrm{L}^{-1}\right)\end{array}$ & $\begin{array}{l}1.343^{\mathrm{c}} \\
\pm 0.15\end{array}$ & $\begin{array}{c}4.003^{c} \pm \\
0.35\end{array}$ & $\begin{array}{c}29.723^{\mathrm{ab}} \\
\pm 25.9\end{array}$ & $\begin{array}{c}37^{\mathrm{a}} \\
\pm 4.71\end{array}$ & $\begin{array}{l}6.83^{\mathrm{bc}} \\
\pm 1.11\end{array}$ & $\begin{array}{c}30.0^{\mathrm{ab}} \\
\pm 31.16\end{array}$ & $\begin{array}{l}8.22^{\mathrm{bc}} \\
\pm 1.67\end{array}$ & $\begin{array}{c}10.67^{\mathrm{bc}} \\
\pm 1.2\end{array}$ \\
\hline $\begin{array}{l}\mathrm{DO} \\
\left(\mathrm{mg} \mathrm{L}^{-1}\right)\end{array}$ & $\begin{array}{c}12.13^{\mathrm{ab}} \\
\pm 0.39\end{array}$ & $\begin{array}{l}6.94^{\mathrm{ab}} \\
\pm 0.34\end{array}$ & $\begin{array}{c}12.37^{\mathrm{ab}} \\
\pm 0.48\end{array}$ & $\begin{array}{l}5.42^{\mathrm{ab}} \\
\pm 0.36\end{array}$ & $\begin{array}{l}7.18^{\mathrm{ab}} \\
\pm 0.27\end{array}$ & $\begin{array}{c}13.24^{\mathrm{ab}} \\
\pm 0.53\end{array}$ & $\begin{array}{l}7.54^{\mathrm{ab}} \\
\pm 0.23\end{array}$ & $\begin{array}{l}6.83^{\mathrm{ab}} \\
\pm 0.27\end{array}$ \\
\hline $\begin{array}{l}\mathrm{BOD} \\
\left(\mathrm{mg} \mathrm{L}^{-1}\right)\end{array}$ & $\begin{array}{l}5.65^{\mathrm{b}} \\
\pm 0.49\end{array}$ & $\begin{array}{l}11.39^{\mathrm{a}} \\
\pm 1.27\end{array}$ & $\begin{array}{l}6.61^{\mathrm{b}} \\
\pm 1.44\end{array}$ & $\begin{array}{c}6.09^{\mathrm{b}} \\
\pm 0.47\end{array}$ & $\begin{array}{c}6.56^{\mathrm{b}} \\
\pm 0.53\end{array}$ & $\begin{array}{l}8.79^{\mathrm{ab}} \\
\pm 0.74\end{array}$ & $\begin{array}{l}9.43^{\mathrm{ab}} \\
\pm 0.76\end{array}$ & $\begin{array}{l}7.67^{\mathrm{ab}} \\
\pm 0.28\end{array}$ \\
\hline $\begin{array}{l}\mathrm{COD} \\
\left(\mathrm{mg} \mathrm{L}^{-1}\right)\end{array}$ & $\begin{array}{l}347.14^{\mathrm{a}} \\
\pm 10.51\end{array}$ & $\begin{array}{c}306.83^{\mathrm{a}} \\
\pm 7.85\end{array}$ & $\begin{array}{c}328.09^{\mathrm{a}} \\
\pm 8.09\end{array}$ & $\begin{array}{c}328^{\mathrm{a}} \pm \\
4.35\end{array}$ & $\begin{array}{c}351.7^{\mathrm{a}} \\
\pm 8.1\end{array}$ & $\begin{array}{c}308.09^{\mathrm{a}} \\
\pm 10.47\end{array}$ & $\begin{array}{c}278.57^{\mathrm{a}} \\
\pm 5.52\end{array}$ & $\begin{array}{l}318.6^{a} \\
\pm 6.16\end{array}$ \\
\hline $\begin{array}{l}\text { phosphate } \\
\left(\mathrm{mg} \mathrm{L}^{-1}\right)\end{array}$ & $\begin{array}{c}0.4^{\mathrm{ab}} \\
\pm 0.05\end{array}$ & $\begin{array}{c}1.19^{\mathrm{ab}} \\
\pm 0.3\end{array}$ & $\begin{array}{l}0.78^{\mathrm{ab}} \\
\pm 0.09\end{array}$ & $\begin{array}{l}2.85^{\mathrm{a}} \\
\pm 0.32\end{array}$ & $\begin{array}{l}0.25^{\mathrm{ab}} \\
\pm 0.04\end{array}$ & $\begin{array}{c}0.61^{\mathrm{ab}} \\
\pm 0.5\end{array}$ & $\begin{array}{l}0.24^{\mathrm{ab}} \\
\pm 0.03\end{array}$ & $\begin{array}{l}0.35^{\mathrm{ab}} \\
\pm 0.03\end{array}$ \\
\hline $\begin{array}{l}\text { Ammonia } \\
\left(\mathrm{mg} \mathrm{L}^{-1}\right)\end{array}$ & $\begin{array}{l}0.31^{\mathrm{b}} \\
\pm 0.04\end{array}$ & $\begin{array}{l}1.89^{\mathrm{a}} \\
\pm 0.28\end{array}$ & $\begin{array}{l}0.81^{\mathrm{ab}} \\
\pm 0.14\end{array}$ & $\begin{array}{l}1.14^{\mathrm{ab}} \\
\pm 0.11\end{array}$ & $\begin{array}{l}1.18^{\mathrm{ab}} \\
\pm 0.24\end{array}$ & $\begin{array}{l}0.44^{\mathrm{ab}} \\
\pm 1.53\end{array}$ & $\begin{array}{l}0.69^{\mathrm{ab}} \\
\pm 0.07\end{array}$ & $\begin{array}{l}0.82^{\mathrm{ab}} \\
\pm 0.09\end{array}$ \\
\hline $\begin{array}{l}\text { Nitrate } \\
\left(\mathrm{mg} \mathrm{L}^{-1}\right)\end{array}$ & $\begin{array}{l}0.07^{\mathrm{b}} \\
\pm 0.02\end{array}$ & $\begin{array}{l}0.32^{\mathrm{a}} \\
\pm 0.03\end{array}$ & $\begin{array}{l}0.19^{\mathrm{ab}} \\
\pm 0.09\end{array}$ & $\begin{array}{l}0.27^{\mathrm{ab}} \\
\pm 0.03\end{array}$ & $\begin{array}{l}0.16^{\mathrm{ab}} \\
\pm 0.03\end{array}$ & $\begin{array}{l}0.11^{\mathrm{b}} \\
\pm 0.11\end{array}$ & $\begin{array}{l}0.17^{\mathrm{ab}} \\
\pm 0.02\end{array}$ & $\begin{array}{l}0.11^{\mathrm{b}} \\
\pm 0.01\end{array}$ \\
\hline
\end{tabular}

Means with the different letters in the same row are significantly $(\mathrm{p}<0.05)$ different (Ducan's Multiple Range Test)

Pehowa in Monsoon season and at Pindara in summer season. The minimum numbers of rotifers were recorded in winters at all the sites. It may be due to the positive relationship of rotifers number with temperature. The relation with high temperature with rotifer abundance has also been reported by Singh, (2000), Sharma (2005) Mondal et al. (2012) Sulehria and Malik (2013) whereas Devi (1997) observed maxima of rotifers during pre-monsoon and monsoon period. The present findings are in contrast to the annual pattern with winter maxima observed in Deepor Bell (Sharma, 2010) and Loktak Pat (Sharma, 2009), whereas Sharma $(1992,2009,2010)$ and Sharma and
Sharma (2012) observed lack of any definite pattern of quantitative variation of the rotifers supporting the present results.

The values of different physico-chemical characteristics are depicted in Table 2. ANOVA revealed significant $(p<0.05)$ variations with respect to sampling sites. However, COD showed so significant variations. Influence of physico-chemical parameter with rotifers abundance was studied by calculating the coefficient of correlation. A positive correlation was observed between rotifer abundance and temperature $(r=0.356$, $\mathrm{P}<0.05)$, with BOD $(\mathrm{r}=0.413, \mathrm{P}<0.05)$ and with Ammonia $(\mathrm{r}=0.378, \mathrm{P}<0.05)$ whereas a negative 
Table 3. Shannon-weaver diversity index (H), Index of Evenness (IE) and Species Dominance Index (SDI) at all the selected water bodies of Brahmsarovar, Pehowa, Pindara, Phalgu, Kirmach, Kapalmochan, Jyotisar and Ban-Ganga.

\begin{tabular}{|c|c|c|c|c|c|c|c|c|c|}
\hline & & Brahms & Pehowa & Pindara & Phalgu & Kirmach & KapalM & Jyotisar & Banganga \\
\hline \multirow[t]{3}{*}{ Summer } & $\mathbf{H}$ & 2.42 & 2.25 & 2.96 & 1.34 & 2.25 & 1 & - & 1.75 \\
\hline & IE & 0.79 & 0.48 & 0.40 & 0.19 & 0.9 & 1 & - & 1 \\
\hline & SDI & 0.21 & 0.30 & 0.19 & 0.63 & 0.21 & 0.47 & - & 0.25 \\
\hline \multirow[t]{3}{*}{ Monsoon } & $\mathbf{H}$ & 3.46 & 0.81 & - & 1.28 & 2.03 & 1.92 & 2.75 & 2.61 \\
\hline & IE & 1 & 0.8 & - & 0.28 & 0.4 & 1 & 0.91 & 0.48 \\
\hline & SDI & 0.09 & 0.62 & - & 0.58 & 0.31 & 0.26 & 0.14 & 0.18 \\
\hline \multirow{3}{*}{$\begin{array}{l}\text { Post } \\
\text { Monsoon }\end{array}$} & $\mathbf{H}$ & 2.24 & 2.72 & - & 0.76 & 3.37 & 1.91 & 1.5 & 2.37 \\
\hline & IE & 0.89 & 0.35 & - & 0.21 & 0.59 & 0.88 & 0.88 & 1 \\
\hline & SDI & 0.22 & 0.26 & - & 0.79 & 0.12 & 0.27 & 0.35 & 0.26 \\
\hline \multirow[t]{3}{*}{ Winter } & $\mathbf{H}$ & - & 1 & - & - & - & 2.58 & - & - \\
\hline & IE & - & 1 & - & - & - & 1 & - & - \\
\hline & SDI & - & 0.50 & - & - & - & 0.15 & - & - \\
\hline \multirow{3}{*}{$\begin{array}{l}\text { Overall } \\
\text { Mean }\end{array}$} & $\mathbf{H}$ & 2.03 & 1.7 & 0.74 & 0.85 & 1.91 & 1.85 & 1.06 & 1.68 \\
\hline & IE & 0.67 & 0.66 & 0.1 & 0.17 & 0.47 & 0.97 & 0.45 & 0.62 \\
\hline & SDI & 0.13 & 0.42 & 0.05 & 0.5 & 0.05 & 0.1 & 0.09 & 0.17 \\
\hline
\end{tabular}

K. cochlearis Anuraeopsis fissa Conochilus Monostyla sp. $2 \quad$ M. bulla M. clasterocerca M. decipiens Lecane arcula L. inapinata

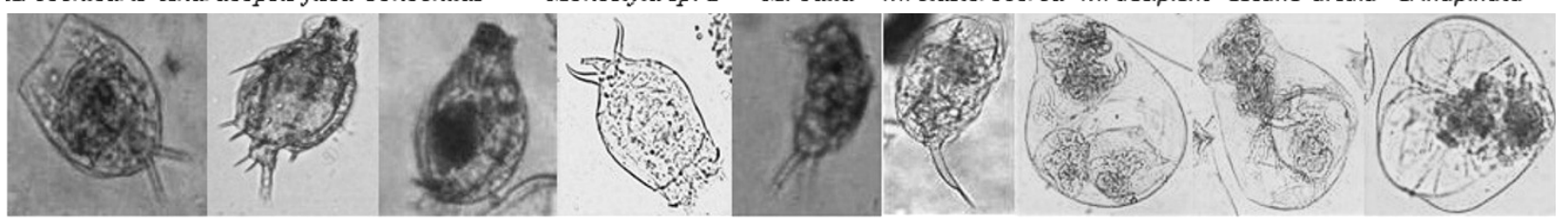

L. ploenensis Testudinella Gastropus Euchlanis dilata Trichocera porcellus T. rattus Asplanchna priodonta A. brightwelli A. herricki

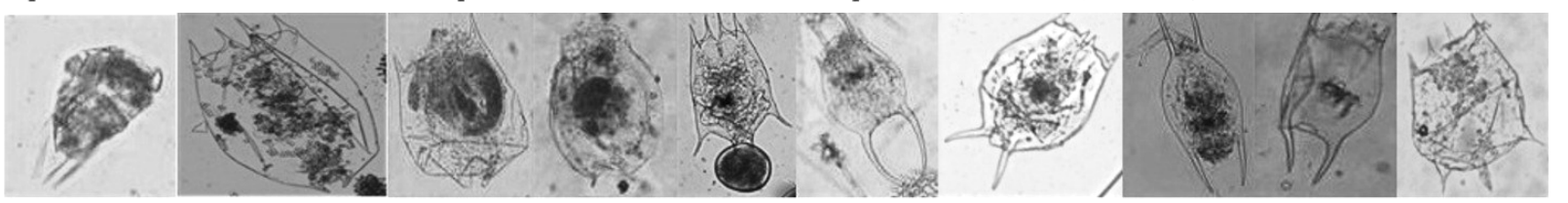

Polyurthera $\quad B$. rubens $\quad B$. bidentatus $B$. calyciflorus $B$. calyciflorus $B$. falcatus $B$. caudatus $B$. diversicornis $B$. quadrata $B$. quadridentatus var. borgerti

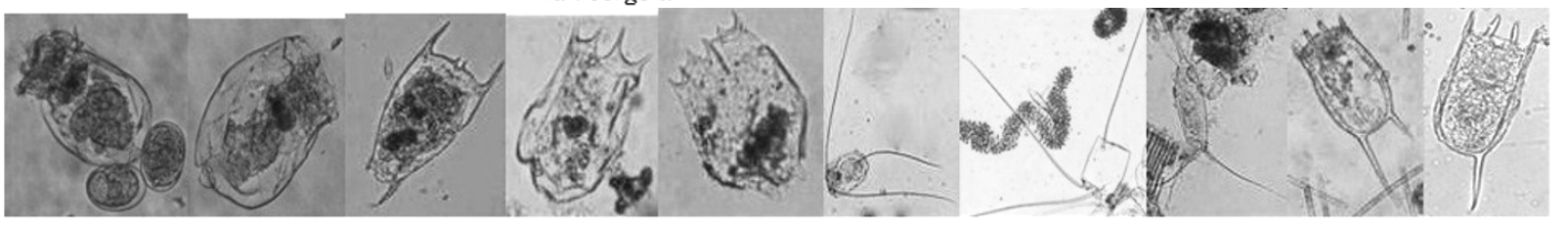

B. plicatilis $\quad B$. dimidiatus $\quad B$. bravispina $B$. budapestinensis $B$. nilsoni Filinia longiseta $F$. longiseta F. terminalis Keratella testudo $K$. tropica

Fig. 3. Microphotographs of different taxa of rotifers encountered.

correlation was observed between rotifer number with DO $(\mathrm{r}=-0.385, \mathrm{P}<0.05)$, supporting the observation of Mondal et al. (2012). The number and composition of species differ due to several important factors such as water temperature, dissolved oxygen, season, water transparency, $\mathrm{pH}$, vegetation, Lake trophy, the depth from which the sample is taken, etc. (Berzins and Pejler, 1987; Berzins and Pejler, 1989a; Berzins and 


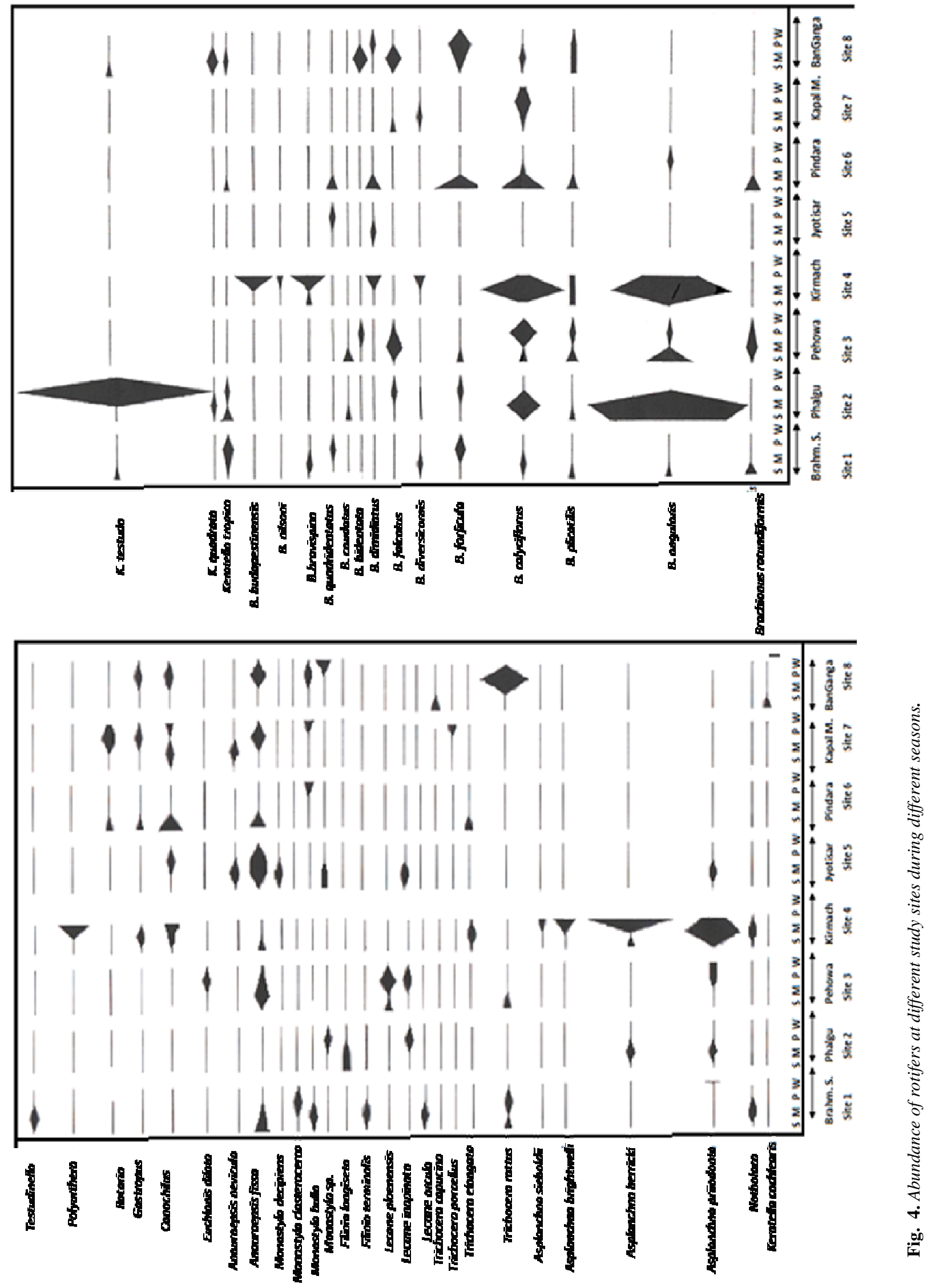


Table 4. Sørensen, 1957 Similarity index among all the selected sites of water bodies of Brahmsarovar, Pehowa, Pindara, Phalgu, Kirmach, Kapalmochan, Jyotisar and Ban-Ganga.

\begin{tabular}{|c|c|c|c|c|c|c|c|c|}
\hline & Brahms & Pehowa & Pindara & Phalgu & Kirmach & KapalM. & Jyotisar & Banganga \\
\hline Brahms & 1 & 0.457 & 0.457 & 0.378 & 0.263 & 0.267 & 0.138 & 0.378 \\
\hline Pehowa & & 1 & 0.4 & 0.909 & 0.316 & 0.16 & 0.25 & 0.5 \\
\hline Pindara & & & 1 & 0.4 & 0.424 & 0.267 & 0.417 & 0.438 \\
\hline Phalgu & & & & 1 & 0.343 & 0.222 & 0.231 & 0.412 \\
\hline Kirmach & & & & & 1 & 0.286 & 0.222 & 0.286 \\
\hline KapalM. & & & & & & 1 & 0.211 & 0.37 \\
\hline Jyotisar & & & & & & & 1 & 0.231 \\
\hline Banganga & & & & & & & & 1 \\
\hline
\end{tabular}

Pejler, 1989b; Field and Prepas, 1997; Line, 1966; Paidere and Skute, 2011). In the present studies Brachionus was observed as the most dominant taxa (figure 4) common to all the study locations. Sulehria and Malik (2013) have also reported the dominance of Brachionus.

Shannon and Weaver Diversity index (Table 3) revealed the highest value 3.46 during monsoon at the site 1 (Brahmarovar), 3.37 in post monsoon season at site 4 (Kirmach), in summer season 2.96 at site 6 (Pindara) and 2.58 the highest value recorded during winters at site 7 (Kapalmochan). Overall mean value of Shannon and Weaver Diversity index was recorded highest (2.03) at Brahmsarovar. This range indicated that these sites had the greater diversity of rotifers throughout the year as this range is near upper limits of Shannon Weaver indices. Such values were also reported by Sulehria and Malik (2013).

The Simpson dominance values (Table 3) ranged between 0.09 and 0.79 , revealing the greater diversity, 0.79 in the month of post monsoon at the site Phalgu and lowest 0.09 in the monsoon at the site Brahmsarovar. Overall mean value of species dominance was recorded highest $(0.42)$ at the site Pehowa and least (0.1) was observed at Pindara. A range from 0.049 to 0.110 was observed by Sharma and Sharma (2012) at the floodplain lake of Brahmputra river basin India.

The value of species evenness (Table 3 ) indices near 1 or equal to 1 shows an even distribution of species throughout the year whereas the values far from 1 show the uneven distribution of species. The species evenness value was found to be 1 at site Kapalmochan, Ban Ganga in summer, at pehowa in winter and at Ban Ganga during post monsoon season, it was 0.9 at Kirmach during summer season showing even distribution of rotifers. High rotifer evenness at these sites clearly depicts the equitable abundance of various species of rotifers and further shows the tolerance of rotifer at varying physico-chemical characteristics. The least value of species evenness 0.199 was observed at site Phalgu in summer revealing the uneven distribution of species at this site. According to overall mean value of species evenness, highest value (0.97) was observed at Kapalmochan whereas least (0.1) at Pindara.

The Sorensen Similarity Index (Table 4 ) was highest between Pehowa and Phalgu (0.909), followed by Ban Ganga and Pehowa (0.5), Pehowa \& Brahmsarovar (0.457), Pindara and Brahmsarovar (0.457), Pindara and Banganga (0.438), Pindara and Kirmach (0.424). Maximum similarity was observed between Phalgu and Pehowa may be due to least geographical distance about $15 \mathrm{~km}$ between two sites. Similarity values between 0.400 and 0.909 i.e. $>40 \%$ at other stations further depict the similar pattern of rotifers even with different types of activities. The values of similarity index were minimum 0.138 and 0.16 between Brahmsarovar \& Jyotisar and Kapalmochan and Pehowa may be because of variation in activity as in Brahmsarovar mass bathing fair is held at every month on new moon day whereas at Jyotisar only at solar eclipse day which was held only one time during the study period. Similarly the value was less for Pehowa and Kapalmochan, here the mass bathing is quite common at Pehowa but at Kapalmochan it is held only on full moon day of October or November.

\section{Conclusion}

The results obtained during the present studies clearly depicted that rotifer community was rich in the stagnant water bodies where different anthropogenic or ritual activities are a regular feature. The most diverse taxa observed in present study was Brachionus, other members of family Asplanachnidae, Trichorceridae, Lecanidae, Filinidae were also dominant. The high similarity index values depicted that different sort of religious activities at different sites had similar effect on rotifer population. The highest species diversity further indicated that rotifers may be considered as tolerant group of zooplanktons, however the stated differences at different sites reflected the 
micro-environmental differences among different sampling sites.

\section{REFERENCES}

Angadi, S.B., Shiddaamallayya, N. and Patil, P.C. (2005). Studies on the Paphas pond, Bidar (Karnataka). Journal of Environmental Biology, 26(2):213-216.

APHA. (2005). Standard methods for the examination of water and waste water. $21^{\text {st }}$ edition, American Public Health Association, Washington

APHA. AWWA. WPCF. (1998). Standard methods for the examination of water and waste water. American Public Health Association, Washington.

Arora, J. and Mehra, K. N. (2003). Species diversity of planktonic and epiphytic rotifers in the backwaters of Delhi segment of the Yamuna river, with remarks on new records from India. Zoological studies, 42(2): 239247.

Battish, S. K. (1992). Rotifers as indicators of trophic nature of environment. Hydrobiologia, 27: 2146-149.

Berzins, B., Pejler, B. (1987). Rotifer occurrence in relation to $\mathrm{pH}$. Hydrobiologia, 147: 107-116.

Berzins, B., Pejler, B. (1989a). Rotifer occurrence in relation to temperature. Hydrobiologia, 175: 223-231.

Berzins, B., Pejler, B. (1989b). Rotifer occurrence in relation to oxygen content. Hydrobiologia, 183: 165-172.

Bhatnagar, A. and Devi, P. (2012). Applications of correlation and regression analysis in assessing lentic water quality: a case study at Brahmsarovar Kurukshetra, India, International Journal of Environmental Sciences, 3(2): 813-820.

Bhatnagar, A. and Sangwan, P. (2009). Impact of Mass Bathing on Water Quality, International Journal of Environment Research, 3(2): 247-252.

Chandra, R. and Prasad, R. N. (2005). Deterioration of water quality during mass bathing in Surya Kund, Lohargal (Rajasthan). Indian Journal of Environmental Biology, 26(2): 205-211.

Devi, S. B. (1997). Present status, potentialities. management and economy of fisheries of two minor reservoirs of Hyderabad. Ph.D. Thesis, Osmania University (Hyderabad, India).

Dhembare, A. J., (2011). Diversity Indices of Rotifer from Dynaneshwar Water Rahuri, Ahmednagar, Maharashtra. European Journal of Experimental Biology, 1(3): 139144.

Dhembare, A. J. (2012). Individual and synchronized correlation between water and Rotifer from Dynaneshwar dam, Ahmednagar, Maharashtra. European Journal of Experimental Biology, 2(1): 122-126.

Duggan, I.C., Green, J. D., Thompson, K., Shiel, R.J. (1998). Rotifers in relation to littoral ecotone structure in lake Rotomanuka, North Island, New Zealand. Hydrobiologia, 113: 77-91.

Edmondson, W. T. (1944). Ecological studies of sessile Rotatoria, Part 1. Factor effecting distribution. Ecology Monograph, 14: 31-66.

Field, K. M. and Prepas, E. E. (1997). Increased abundance and depth distribution of pelagic crustacean zooplankton during hypolimnetic oxygenation in a deep, eutrotrophic Albert Lake. Canadian Journal of Fisheries and Aquatic, 54:2146-2156.

Golterman, H. L., Clymo, R. S. and Ohnstand, M. A. M. (1978). Methods for physical and chemical analysis.IBP
Handbook No. 8, second Edition, Blackwell Scientific Publication, Oxford, pp. 172.

Hill, M. O. (1973). Diversity and evenness: a unifying notation and its consequences. Ecology 54: 427-432.

Kulshreshtha, H. and Sharma, S. (2006). Impact of mass bathing during Ardhkumbh on water quality status of river Ganga. Journal of Environmental Biology, 27 (2):437- 440 .

Kumar, A. and Tripathi, S. (2004). Zooplankton diversity in relation to aquaculture in some ponds of Durg Bhilai city, Chattishgarh state. Journal of Nature Environment Pollution and Technology, 3(2): 175-178.

Leinster, T. and Cobbold, C. A. (2012). Measuring diversity: the importance of species similarity. Ecology, 93(3): 477-489.

Line, R. 1(966). Latvijas PSR austrumu un centrālās daḷas ezeru zooplanktona sastāvs, kvantitatīvā attīstība un perspektīvā izmantošana. Disertācija. Latvijas PSR Zinātņu akadēmijas Biologíijas institūts. Rīga. 279.

Mondal, D., Pal, J., Ghosh, T. K. and Biswas, A. K. (2012). Rotifer diversity of Mirik Lake in Darjeeling Himalaya. European Journal of Experimental Biology, 2(5): 14511456.

Needham, G. and Needham, R. (1962). Guide to study freshwater Biology. Holden Day, San Francisco.

Paidere J., Škute R. (2011). Virpotāji (Rotifera) un to fauna Latvijā. Daugavpils, Daugavpils Universitāte, pp. 272.

Paleolog, A., Radwan, S., Kowalik, W., Kowalczyk, C., Stryjecki, R. and Zwolski, W. (1997). Water invertebrates of Lasy Janowskie landscape park. In: Naural Environment of Lasy Janowskie landscape park (Ed. S. Radwan). UMCS Press, Lublin, pp. 83-227 (in Polish).

Shannon, E.E. and Weaver, W. (1963). The mathematical theory of communication. Univ. of Illinois. Press Urhana. pp:117.

Sharma, B. K. (1992). Systematics, Distribution and Ecology of Freshwater rotifer in west Bengal. In: Recent Advances in aquatic Ecology (S. R. Mishra \& D. N. Saksena Rds.). Ashish Publishing House, New Delhi. pp. 231-273.

Sharma, B. K. (2005). Rotifer communities of floodplain lakes of the Brahmputra river basin of lower Assam (N. E, India): biodiversity, distribution and ecology. Hydrobiologia, 533: 209-221.

Sharma, B. K. (2009). Diversity of rotifers (Rotifera, Euratatoria ) of Laktal lake, Manipur, North- eastern India. Tropical Ecology, 50(2): 277-285.

Sharma, B. K. (2010). Rotifer communities of Deepor beel. Assam, India:richness, abundance and ecology. Journal of Threatened Taxa, 2(8): 1077-1086.

Sharma, B. K. and Sharma, S. (2012). Rotifer diversity of Floodpalain Lake of the Brahmputra river basin of lower Assam, Northeast India. Opuscula Zoologica (Budapest), 43(1): 67-77

Simpson, E.H. (1949). Measurement of diversity. Nature, 163: 688

Singh, D. N. (2000). Evaluation of Physico-chemical parameters in Oxbow lake, Geobios, 27: 120-124.

Sinha, A.K., Pande, D.P., Srivastava, R.K., Srivastava, P., Srivastava, K.N., Kumar, A. and Tripathi, A. (1991). Impact of bathing on the water quality of the Ganga River at Haudeshwarnath (Partapgarh), India-a case study. Science of the Total Environment, 101(3):275280. 
Sørensen, T. (1957). A method of establishing groups of equal amplitude in plant sociology based on similarity of species and its application to analyses of the vegetation on Danish commons. Kongelige Danske Videnskabernes Selskab5 (4): 1-34.

Sulehria, A.Q.K. and Malik, M.A. (2013). Diversity indices of pelagic rotifers in Camp Balloki water park, Lahore, Pakistan. Turkish Journal of Zoology, 37:699-705.

Sulehria, A.Q.K., Qamar, M.F., Anjum, R.F., Ejaz, M. and Hussain, A. (2009a). Seasonal fluctuations of Rotifers in a fish pond at District Bahawalnagar, Pakistan. Biologia (Pakistan), 55(1 \& 2): 21-28.

Tiwari, A. and Chauhan, S.V.S. (2006). Seasonal phytoplankton diversity of Kitham Lake. Journal of Environmental Biology, 27(1):35-38.

Turchi, G. M., Kennedy, P. L., Urban, D. and Hein, D. (1995). Bird species richness in relation to isolation of aspen habitats. Wilson Bulletin, 107: 463-474.

Wallace, R. L. (1977). Distribution of sessile rotifers in acid bog pond. Archiv für Hydrobiologi., 79: 478505.

Wallace, R. L. (1980). Ecology of sessile rotifers. Hydrobiologia, 73:181-193.

Ward, H.B. and Whipple, G.C. (1959). Freshwater biology. John Wiley and sons. pp: 1248. 